\title{
The sustainability of rainwater harvesting for supplying domestic water demand in Yogyakarta City
}

\author{
Basyar I. Arijuddin ${ }^{1}$, Ig. L. Setyawan Purnama², and Emilya Nurjani² \\ ${ }^{1}$ Faculty of Geography, Universitas Gadjah Mada, Indonesia \\ ${ }^{2}$ Department of Environmental Geography, Faculty of Geography, Universitas Gadjah Mada, Indonesia
}

\begin{abstract}
Yogyakarta city has a problem of water resources management along with the rapid development in this region. Rainwater harvesting $(\mathrm{RWH})$ can be an alternative choice in urban water resources management. This study aims to determine the best RWH scenario as a sustainable water supply to meet domestic water demand in Yogyakarta City. The method used is the Sustainability Index with 3 parameters including reliability, resilience and vulnerability. Each parameter is a derivative of a water balance simulation of the RWH system using the data range in the period 2006-2015. This study compares the percentage of roof usage in the RWH system and the level of domestic water demand. The results of this study indicate that the RWH scenario by utilizing $50 \%-75 \%$ of the roof area can be ideally meet up to $80 \%$ of domestic water needs in Yogyakarta City. RWH scenario with $100 \%$ roof usage can meet all domestic water needs well. This study shows that the RWH system can have a positive impact on the management and sustainability of water resources in Yogyakarta City.
\end{abstract}

\section{Introduction}

Rapid development in urban areas in Indonesia causes complex problems in spatial land use. Land use for settlements and urban infrastructure development is contrary to the provision of land for food and clean water management [1]. The area of green open space, which functions as a local catchment area and ecological balance, tends to decrease. Meanwhile, due to the increasingly high population pressure, land in urban areas has changed into a built-in land that is impermeable. This condition causes an increased risk of flooding and reduced groundwater supply at the local level. On the other hand, a large population in urban areas has consequences for high water demand. The imbalance between water supply and demand in urban areas is an important issue, especially in the context of sustainable development.

Yogyakarta city is an urban area in Indonesia that has these problems. This region with a population density of 12,699 people $/ \mathrm{km} 2$ is one of the highest in Indonesia [2]. The challenge that must be solved is the provision and management of sustainable water resources with limited space. Conventional water use in Yogyakarta city still uses groundwater as the main source to meet demand from various sectors [3]. Reduced water catchment areas and increased demand for water for a long time can increase the potential for a water crisis in the region. A very high level of vulnerability is predicted to threaten $91.6 \%$ of areas in Yogyakarta city due to limited groundwater reserves [4]. The average groundwater level has decreased by 1 meter every 3 years [5]. Yogyakarta city only has the carrying capacity of water resources for the next 4 decades if there is no good conservation and water management system [6]. This condition worries about the sustainability of water resources in Yogyakarta city.

Most of the water demand in Yogyakarta city comes from the domestic sector, therefore the community will be one that is exposed to the direct impact of the water crisis problem in this region. Domestic water demand is one of the focus issues that need to be resolved in the study. Diversification of water resource management can be used to optimize water resource reserves $[7,8]$. Rainwater is rarely used for non-agricultural purposes such as domestic. The use of rainwater for daily consumption is only applied by $1 \%$ of the world's population or $2.46 \%$ of the population in Indonesia [9]. Generally, the use of rainwater is applied by rural communities. In Yogyakarta, the management of rainwater by harvesting through the roofs of buildings has been applied by rural communities in Gunungkidul [10]. Rainwater harvesting (RWH) can be a water resources management system in urban areas to optimize water supply. High rainfall potential as a tropical region, supported by a large number of roofs in Yogyakarta city can be a good capital for applying RWH systems. This study examines the performance of the RWH system if applied in Yogyakarta as a method to increase the capacity of water resources to meet water demand.

\section{Methods}

The concept of water balance in a hydrological system is the basis used to evaluate and analyze the sustainability of the RWH system in this study. The input in the hydrological system is always balanced with the output

\footnotetext{
Corresponding author: basyar.ihsan.a@mail.ugm.ac.id
} 
and water storages. This study assumes the amount of water availability produced by RWH as input and the amount of domestic water demand as output. The sustainability parameter is derived from the performance of the water balance simulation system. Generally, there are three steps to obtain the sustainability index, among others: simulation of water balance, calculate the value of three parameters of performance system, calculate the composite value of parameter used as the value of sustainability index.

\subsection{Research area}

This research area is located in Yogyakarta City. The total area is $\pm 32.5 \mathrm{~km}^{2}$, which is the smallest area in the Special Region of Yogyakarta (only about $1.02 \%$ of the province). This area has complex characteristics. Population in Yogyakarta City is one of the most densely populated in Indonesia around 12,699 in habitants $/ \mathrm{km}^{2}$ [2]. The city of Yogyakarta consists of 14 districts and has a border with Sleman and Bantul regency. The development of the city is generally influenced by the education, services and tourism sectors and a small proportion of the industrial sector. The characteristics of
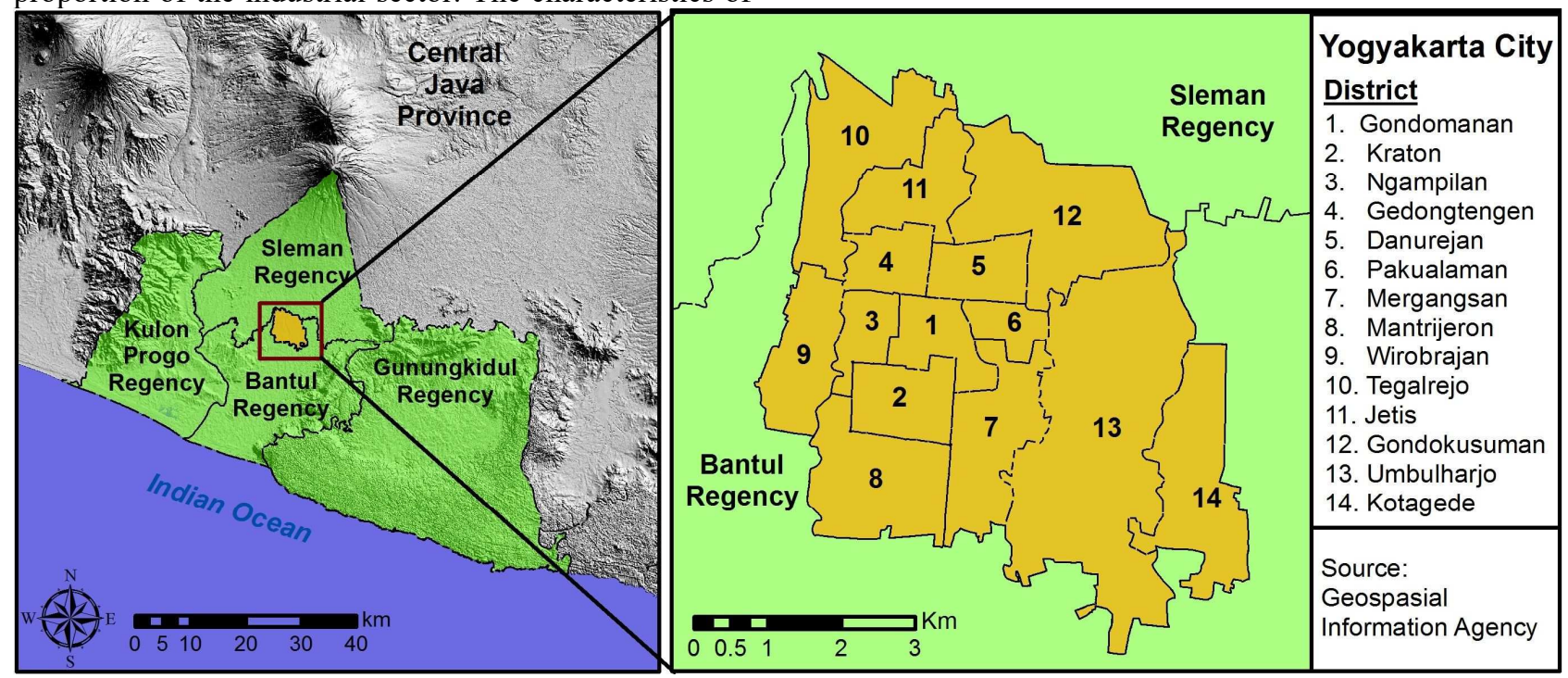

the region are very interesting to make research on the potential of RWH system applications in this area.

\subsection{Water balance simulation}

The mathematical equation representing the water balance is known as the water budget equation [11].

$$
I-O=\frac{\Delta S}{\Delta t}
$$

Water storage $(\Delta S)$ by the time $(\Delta t)$ will always be equal to the difference between input (I) and the Output (O). Loucks (1997) uses an approach to assess performance system on the behavior of hydrological systems to the environment. Hydrological system has a threshold to meet the water demands required by the environment, in this case urban society. Hydrologic system is a function of supply and water needs of the environment as a function of demand. Performance system is to be feasible if the supply is still below the threshold. This concept can be seen in Figure 1.
Fig. 1. Map of research area.

The performance identified optimally if it exists in areas of acceptable value. If it passes an improper value then the system shows a failure in its performance. This research uses the availability of RWH as a water supply with domestic water requirement as its demand. Equation (2) can be modified into the following equation.

$$
s_{\text {RWH }}-D_{w d}=\frac{\Delta s}{\Delta t}
$$

RWH water supply $\left(\mathrm{S}_{\mathrm{RWH}}\right)$ as input in system and domestic water requirement $\left(\mathrm{D}_{\mathrm{Wd}}\right)$ as its output. The difference between supply and demand is the change in water reserves $(\Delta \mathrm{S} / \Delta \mathrm{t})$. Failure in the RWH system occurs when $\Delta \mathrm{S} / \Delta \mathrm{t}$ value is negative, this condition can also be called a deficit. Conversely, if the water supply is greater than the demand, then $\Delta \mathrm{S} / \Delta \mathrm{t}$ is a positive value called surplus or satisfactory value.

The water supply provided by RWH is the multiplication function of rainfall $(\mathrm{R})$, the area of the roof catch $(\mathrm{A})$ and the run off roof $(\mathrm{Cr})$ coefficient. Here is the equation for measuring the modified $\mathrm{S}_{\mathrm{RWH}}$ [12].

$$
S_{\text {RWN }}=R \times A \times C r
$$

The value of $R$ is measured in units of $m /$ day or $\mathrm{m} / \mathrm{month}$ depending on the available data. The rain data in this study was obtained from the Agriculture Office of Yogyakarta City. The value of A is the extent of the roof used as a water catchment in units of $\mathrm{m}^{2}$. This value can be either a roof for a single house or the accumulation of roof space depending on the analysis conducted. $\mathrm{Cr}$ is a runoff coefficient that has a range of $0-1$ values, this 
study uses a value of 0.8 which is suitable for roof tile type.

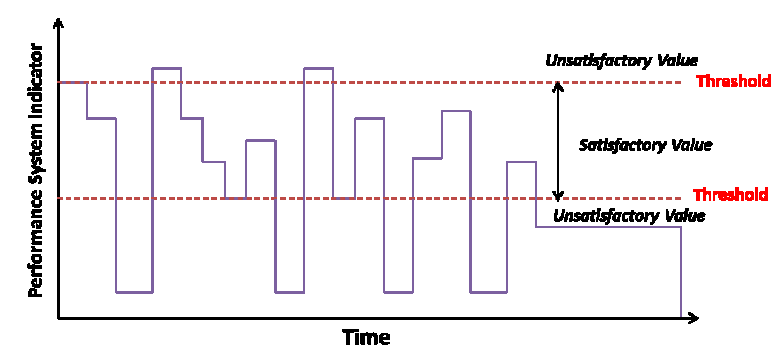

Fig. 2. System performance derived from simulation model (Loucks, 1997).

\subsection{Performance system criteria}

The performance of the RWH system is observed through the water balance between $\mathrm{S}_{\mathrm{RWH}}$ and $\mathrm{D}_{\mathrm{Wd}}$ over a specified period. The value of $\mathrm{S}_{\mathrm{RWH}}$ is dynamic depending on the volume fluctuation produced every time while the Demand value is assumed to be constant with the average value of domestic water consumption in Yogyakarta 178,09 liters/capita/days [10]. Changes in water reserves $(\Delta \mathrm{S} / \Delta \mathrm{t})$ in observing the performance of the RWH system provide a description of its feasibility and its sustainability in meeting domestic water needs. Hashimoto et al. in 1982 introduced a measuring instrument to determine the sustainability of system performance through three parameters namely reliability, resilience, and vulnerability. The concept can be applied to determine the performance of a hydrological system such as the approach used by Loucks in 1997. Solis et al. in 2011 offers a mathematical solution through a sustainability index to facilitate policy-making. Mathematically the performance criteria are defined as follows.

$$
P_{t-1}=\left\{\begin{array}{c}
\text { unsatisf actory }(0) \\
\text { satisfactory }(1) \text { if } s_{R W H} \times s_{W W}
\end{array}\right.
$$

System performance $(\mathrm{P})$ in period $\mathrm{i}(\mathrm{t})$ has a value of 0 if the water supply is smaller than demand. The value of unsatisfactory is a water deficit where the PAH system fails to meet its needs and therefore has no storage. The satisfactory value is the amount of surplus that can be used as water savings.

Reliability is the probability of a surplus or satisfactory value within a period of observation defined as:

$$
R \theta l_{i}=\frac{\text { Latisfactory }}{n_{t-i}}
$$

Resilience (Res) is the probability of system recovery after failure is measured by comparing the satisfactory value following the unsatisfactory value with the number of unsatisfactory values in the period.

$$
\operatorname{Res}_{\mathrm{i}}=\frac{\sum \text { satisfactory follows unatis factory }}{\mathrm{\Sigma}_{\mathrm{i}=\mathrm{i}}^{i} \text { unsatiswactory }}
$$

Vulnerability (vul) is the severity of the failure period in the system performance measured by comparing the average deficit in period to the total water requirement. The average water deficit is calculated by dividing the total deficit by the number of deficit periods or unsatisfactory value.

$$
V u d_{i}=\frac{2 \text { deficit value } / \sum_{i=1}^{i} \text { unsatisvactory }}{\sum D_{W d}}
$$

\subsection{Sustainability index}

The Sustainability Index is a combination of the three parameters compiled by Louck (1997) and modified Solis et al. (2011) to the following:

$$
S I=[\operatorname{Rel} x \operatorname{Res} x(1-V u l)]^{1 / 2}
$$

SI values can be observed through various scenarios designed to determine the best system performance. Aydin et al. (2014) classifies SI into 4 states as in Table 1.

Table 1. State Perform System with SI (Value Aydin et al., 2004).

\begin{tabular}{|c|c|}
\hline SI Value & State \\
\hline$<0.25$ & Unacceptable \\
\hline $0.25<\mathrm{SI}<0.5$ & Moderate \\
\hline $0.5<\mathrm{SI}<0.75$ & Acceptable \\
\hline$>0.75$ & Ideal \\
\hline
\end{tabular}

\section{Results and discussions}

Yogyakarta city has an average rainfall of $1813 \mathrm{~mm} /$ year during the period 2006-2015. Figure 3 shows the average monthly rainfall in Yogyakarta city obtained by measuring the average of regional rainfall based on isohyet interpolation. The highest rainfall usually occurs in December to February with a thickness of more than $275 \mathrm{~mm}$ per month. The dry period occurs in June to September with rainfall below $50 \mathrm{~mm}$ every month. The average daily rainfall in Yogyakarta City ranges from 10-17 mm, meaning the potential of rain that can be collected by the roof area of $1 \mathrm{~m}^{2}$ every time the rain reaches 8-136 L. Rain type in Yogyakarta City is monsoon which has the difference of wet season and dry season. This type is regionally influenced by Asian monsoon and Australian monsoon.

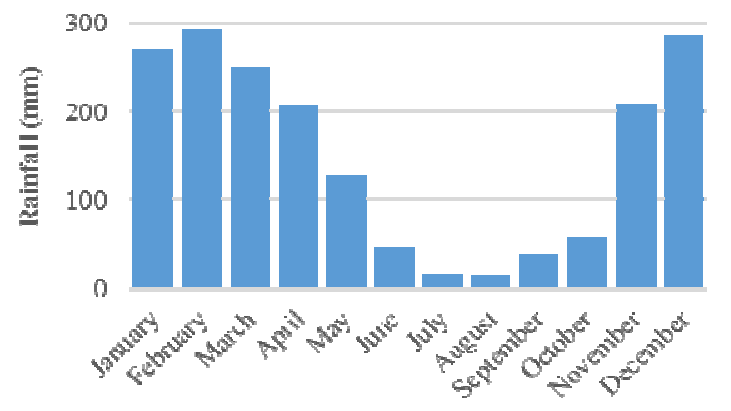

Fig. 3. Monthly average rainfall in Yogyakarta City. 
The total roof area of residential buildings in the city of Yogyakarta reached 14.73 million $\mathrm{m}^{2}$. The settlements in Yogyakarta city mostly have roof tile type. Therefore, the coefficient of runoff used is 0.8 equal to the dominant roof type. Potential water supply can be produced by RWH System in Yogyakarta City is \pm 22.33 million $\mathrm{m}^{3} /$ year, if all settlement building utilizes its roof area to catch rainwater. On the other hand, an average value of domestic water consumption in Yogyakarta City is 178.09 liters/capita/day [13]. Domestic water demands in Yogyakarta City estimated 27.12 million $\mathrm{m}^{3} /$ year with population 412 thousand inhabitants [2].

In general, RWH water supply is not equivalent to its domestic water demands. This gives a value that is not as high as the expected system performance. Figure 3 shows the simulation of RWH system performance in Yogyakarta city in one year. Unsatisfactory value occurs on the $200^{\text {th }}-300^{\text {th }}$ day encountered from late July to October. Potential system failures can occur due to the reduction of rainfall especially in early June so that the existing water storage are only able to function optimally during the next month. When the failure period occurs, there are several times bounce back but due to low water supply so cannot consistently have optimal performance.

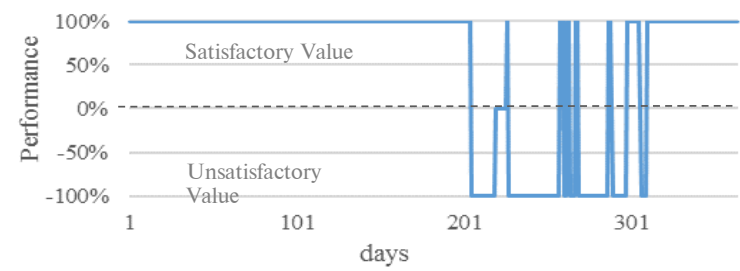

Fig. 4. Performance of scenario RWH system in Yogyakarta City.
The Sustainability Index (SI) can be used in various scenario models to identify the different types of management of observed water resources [14]. This study uses 3 SI value observation scenarios based on the roof area used with the level of water requirement as seen in Figure 4. The utilization of $100 \%$ of the catchment area gives a very optimum result in providing a large water supply but this is very difficult to be realized in the real world. Besides still a new thing in some people of Yogyakarta City, the level of trust for RWH as urban water source is still uncertain. Nevertheless, the utilization of all residential roof areas in Yogyakarta City has a high level of reliability as a source for domestic water demands.

RWH system has high reliability with value more than 0.75 to meet all domestic water demand in Yogyakarta City. This high level of reliability is followed by a low level of vulnerability (below 0.25 ) and a more variable resilience. Resilience levels are difficult to predict, especially with long historical data [15]. Resilience has been debated as an indicator in evaluating the sustainability of water resources because the value is very random and does not have a clear pattern. The existence of resiliency and vulnerability measurements in determining performance criteria because they were less able to accurately represent time of sojourn [16]. This study solves the problem by taking into account the remaining water reserves during a bounce back to meet demand until the next bounce back period. The result is a more real SI value can be obtained because it takes into account the length and capacity of the RWH system when trying to return to its best performance.
$100 \%$ Roof Catchment

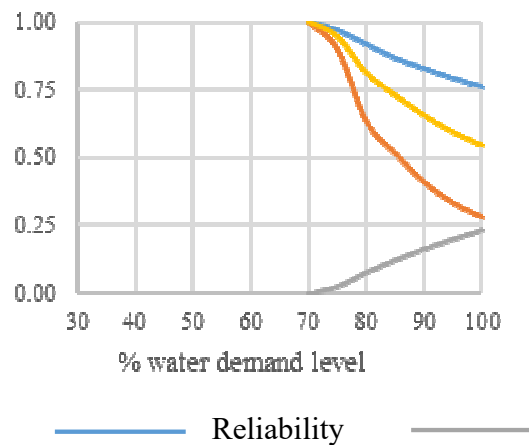

75\% Roof Catchment

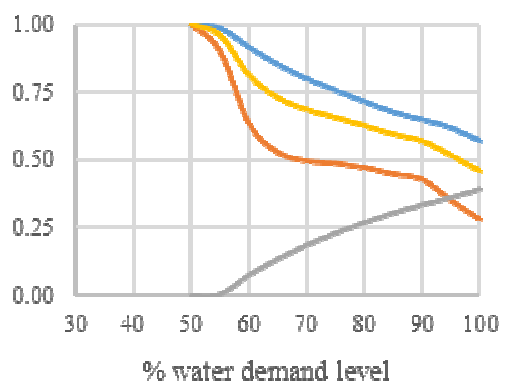

Resilience

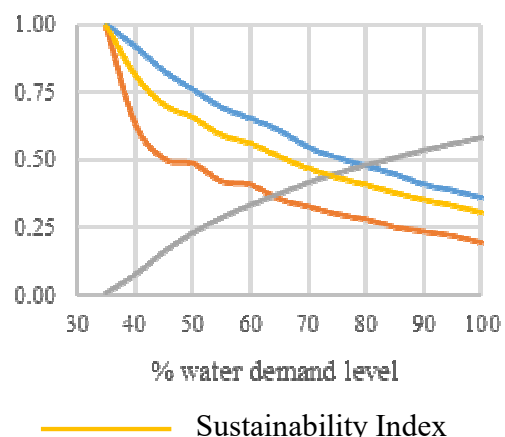

Sustainability Index

Fig. 5. Sustainability Index 3 scenario RWH in Yogyakarta City.

The SI value for $100 \%$ roof catchment is more than 0.5 which means that in general the RWH system can optimally supply domestic water demand. In the scenario of $75 \%$ and $50 \%$ roof catchment, the RWH system capability is declining but the lower water demand level will have a good effect on the sustainability value. Scenario for $75 \%$ roof catchment seen intersection between vulnerability with resiliency which shows instability of RWH system in supplying water demand at certain level. Consequently, there is a decrease in SI value to be lower than 0.5 with moderate sustainability. This condition indicates that the RWH system has not been able to supply water demand at $100 \%$ optimally, so the allocation of water demand should be used at a lower level. Ideal condition of this scenario (SI > 0.75) at level of water demand $62 \%$ with limits of performance system state acceptable level of water demand $97 \%$ In scenario of $50 \%$ roof catchment, RWH performance 
capability has ideal conditions at level of water demand $50 \%$, with system performance capability limits at state acceptable at level of water demand $80 \%$.

Allocation of water demand level below $100 \%$ means there must be other water sources to meet the water requirements outside of the RWH system. For example, in scenario of $50 \%$ roof catchment, the ideal water demand level used is $50 \%$ so that the allocation of half the domestic water demands of the community uses RWH and the other half can use groundwater. This can certainly reduce groundwater consumption significantly if the RWH system can be used by most or all of the people in Yogyakarta City. The partial use of the roof as a catch in the RWH system can also be combined with other water resource conservation methods such as infiltration wells. The roof catchment which is not used in the RWH system can be conveyed on infiltration wells so that the storage of groundwater can be maintained sustainably. This technique requires further research related to the combination model that can be generated from the rain harvesting system through the roof. Historical data in sustainability observations on water supply systems can show better results because changes in hydro-meteorological conditions due to climate change can be well predicted [17].

\section{Conclusion}

Rainwater harvesting can have an impact on the sustainability of water resources in Yogyakarta City. Generally, this area has good potential for rainwater availability but it is not distributed equally. The various scenarios in this study is showing that water demand can be served by the RWH system. The use of all parts of the roof is very reliable to serve all domestic water demand in Yogyakarta City, but the resilience of the RWH system has a wide range of values. The scenario is very difficult to be realized because the RWH system has not been popular among the people of Yogyakarta City. This study shows other scenarios with the use of $75 \%$ and 50 $\%$ of roof catchments to supply domestic water demand. The result of observation of SI value indicates that RWH system can be used with acceptable state up to $80 \%$ level of domestic water demand to use half of roof catchment. Others from domestic water demand can be supplied from other water sources such as groundwater. The utilization of RWH will reduce the environmental pressure on groundwater as the main water supply in Yogyakarta city today. This method can be combined with other water conservation techniques such as infiltration wells through unused roofs in the RWH system. The conclusion from this research is, RWH gives its renewal and contribution to the sustainability of water resources in Yogyakarta City

\section{References}

1. H.S. Yunus. Megapolitan: Concepts, Problems and Prospects. (2010) Pustaka Pelajar, Yogyakarta

2. BPS. Kota Yogyakarta in Figure 2016.

3. Sudarmadji, Some Notes on Groundwater as a Domestic Water Supply of the Yogyakarta Municipality. The Indonesian Journal of Geopgraphy. 26, 1-10 (1994)

4. Brontowiyono. Sustainable Water Resources Management with Special Reference to Rainwater Harvesting: Case Study of KartaManTul, Java, Indonesia. Dissertation. Universitat Fridericiana Karlsruhe (2008)

5. Haryanto. Assessment of Land Availability and Public Awareness of Rainwater Conservation Opportunities in Yogyakarta City. Thesis. Universitas Gadjah Mada (2007)

6. B. Widodo, R. Lupyanto, B. Sulistiono, D.A. Harjito, J. Hamidin, E. Hapsari, M. Yasin, and C. Ellinda. Analysis of Environmental Carriying Capacity for the Development of Sustainable Settlement in Yogyakarta Urban Area. Procedia Environmental Science. 28, 519-521 (2005)

7. P.H. Gleik. The changing water paradigm: a look at twenty-first century water resources development. Water International. 25, 127-138 (2000)

8. G.W. Miller. Integrated Concepts in Water Reuse: Managing Global Water Needs. Desalination. 187, 65-75 (2006)

9. United Nation Children's Fund (UNICEF) dan World Health Organization (WHO). Progress on Drinking Water and Demand Sanitation-2015 Update and MDGs Assessment. WHO Press, Geneva (2015)

10. B.I. Arijuddin. Analysis of the water availability to meet domestic water demand in Hargosari Village, Tanjungsari District, Regency of Gunungkidul. Thesis. Universitas Gadjah Mada (2014)

11. R.H. McCuen. Hydrologic Analysis and Design. Prentice Hall Inc., New Jersey (1998)

12. C.A. Novak, E.V. Giesen, and K.M. Debusk. Designing Rainwater Harvesting System: Integrating Rainwater into Building System. John Willey and Sons, New Jersey (2014)

13. B.I. Arijuddin. Roof-Based Rainwater Harvesting for Supplying Domestic Water Demand in Yogyakarta City. Thesis UGM, Yogyakarta (2018)

14. S.S. Solis, D.C. McKinney, and D.P. Loucks. Sustainability Index for Water Resources Planning and Management. Journal of Water Resources Planning and Management. 137, 381-390 (2011)

15. T.R. Kjeldsen and D.Rosbjerg. Choice of reliability, resiliency, and vulnerability estimators for risk assessment of water resources system. Journal des Sciences Hydrologique. 49, 755-767 (2004) 
16. Z. W. Kundzewicz and J.Kindler. Multiple Criteria for Evaluation of Reliability Aspects of Water Resources Systems. Proceedings of a Boulder Symposium IAHS 231, 217-224 (1995)

17. Z. Srdjevic and B. Srdjevic. An Extension of the Sustainability Index Definition in Water Resources Planning and Management. Water Resources Management (2017)

18. D.P. Loucks. Quantifying trends in system sustainability. Journal des Sciences Hydrologique. 42, 513-530 (1997)

19. T. Hashimoto, J.R. Stedinger and D.P. Loucks. Reliability, Resieliency and Vulnerability Criteria for Water Resources System Performance Evaluation. Water Resources Reasearch. 18, 14-20 (1982)

20. N.Y. Aydin, L. Mays, and T. Schmitt. Sustainability assessment of urban water distribution system. Water Resources Management. 28, 4373-4384 (2014)

21. T. Asefa, J. Clayton, A. Adams, and D. Anderson. Performance evaluation of a water resources system under varying climatic conditions: Reliability, Resilience, Vulnerability and beyond. Journal of Hydrology 508, 53-65 (2014)

22. B. Susilo. Spatial Modeling of Land Use Dynamics in Urban Areas of Yogyakarta. Dissertation. UGM, Yogyakarta (2016) 